\title{
Water relations of cassava cultivated under water-deficit levels
}

\author{
Laís Fernanda Melo Pereira ${ }^{1}$. Samara Zanetti ${ }^{1} \cdot$ Marcelo de Almeida Silva $^{1}$
}

Received: 18 July 2017 / Revised: 2 October 2017 / Accepted: 9 December 2017 / Published online: 14 December 2017

(c) Franciszek Górski Institute of Plant Physiology, Polish Academy of Sciences, Kraków 2017

\begin{abstract}
The tolerance of plants to water deficit involves a series of adaptive mechanisms; however, little is known about the physiological characteristics of cassava (Manihot esculenta Crantz), which is one of the most tolerant crops to adverse environmental conditions. The objective of this work was to evaluate the water relations in cassava plants subjected to different levels of water deficit. The treatments were conducted in three evaluation periods $(0,45$ and 90 days after water deficit $)$ and at three soil water tensions $(-10,-40$ and $-70 \mathrm{kPa})$, with five replicates. The plants were mainly affected at 45 days after the water deficit, with an increase of $42.9 \%$ in total chlorophyll content and $35.3 \%$ in carotenoid content in plants under a tension of $-70 \mathrm{kPa}$; however, these plants reduced by $30.8 \%$ chlorophyll $a$ content at 90 days of the treatments. The water potential, relative water content and electrolyte leakage in the leaf were not altered by the soil water tension. There was an increase of $35.4 \%$ in stomatal density independent of soil water status at 90 days and of $16.0 \%$ under tensions of -40 and $-70 \mathrm{kPa}$; however, the effective quantum efficiency of photosystem II and rate of electron transport were reduced. Cassava can maintain a leaf water potential close to $-0.3 \mathrm{MPa}$ in the predawn and the integrity of the cell membranes in leaves under a soil water tension of up to $-70 \mathrm{kPa}$.
\end{abstract}

Keywords Manihot esculenta $\cdot$ Drought $\cdot$ Chlorophyll $\cdot$ Water potential $\cdot$ Fluorescence $\cdot$ Stomatal density

\section{Introduction}

Cassava (Manihot esculenta Crantz) is a perennial plant, a heliophyte, and a tuberous root shrub that belongs to the Euphorbiaceae family and is one of the main food sources of energy in developing countries (Alves 2002). Its starchy tuberous roots are used in human food and feed for animals and as a raw material for the food, textile and paper industries (Santisopasri et al. 2001).

Cassava is a drought-tolerant plant and is commonly produced in areas that receive less than $700 \mathrm{~mm}$ of rain per year and have a dry season of 4-6 months (El-Sharkawy 2012). However, the period of greatest susceptibility of the crop to water deficit is approximately $30-150$ days after planting (Oliveira et al. 1982). The reduction in yield of tuberous roots depends on the duration of the water deficit and is

Communicated by R. Aroca.

Marcelo de Almeida Silva

marcelosilva@fca.unesp.br

1 School of Agricultural Sciences, UNESP-São Paulo State University, PO Box 237, Botucatu, SP 18603-970, Brazil determined by the sensitivity of a particular phenological stage to stress (Lebot 2009).

A water deficit can be defined as the entire water content of a tissue or cell that is below the water content of maximum hydration (Taiz and Zeiger 2013). Reduction of water potential affects all activities that depend on turgor, such as cell division and stretching, photosynthesis, respiration, translocation, ion absorption and nutrient metabolism. Photosynthesis is one of the variables that show great sensitivity to drought (Lawlor and Tezara 2009; Inman-Bamber and Smith 2005).

Photosynthetic pigments are often used to estimate the photosynthetic capacity of plants because their contents can vary between species as well as between genotypes of the same species (Baret et al. 2007; Ciganda et al. 2008). In stress environments such as drought, the occurrence of inhibition or reduction in electron transfer at the photochemical stage of plant photosynthesis is reflected by an increase in chlorophyll fluorescence $a$ (Maxwell and Johnson 2000), and the excess energy absorbed by the pigments is mainly dissipated because of water deficiency and the limitation in the assimilation of $\mathrm{CO}_{2}$. 
The reduction of leaf stomatal conductance in plants in a water deficit condition is of paramount importance to avoid severe water loss and thus to protect the photosynthetic systems and cellular structures from irreversible damage (Duque and Setter 2013). The physiological and developmental mechanisms that allow a species to tolerate prolonged periods of water deficit may involve various attributes (Alves and Setter 2004) that depend on the genotype, the stage of plant development, and the duration and severity of the stress (Bray 1993; Santos and Carlesso 1998).

Therefore, the objective of this research was to evaluate the water relations in cassava plants under three soil water tensions during the phenological stage between 90 and 180 days after planting.

\section{Materials and methods}

\section{Description of the experimental area and treatments}

The experiment was carried out in a protected environment at the School of Agricultural Sciences-FCA/UNESP, located in Botucatu $\left(22^{\circ} 51^{\prime} \mathrm{S}, 48^{\circ} 26^{\prime} \mathrm{W}\right.$ and $786 \mathrm{~m}$ above sea level) in the State of São Paulo, Brazil. The protected environment was a wooden structure and galvanized steel arches with the right foot of $3 \mathrm{~m}$ in a total area of $120 \mathrm{~m}^{2}$ with anti-aphid fabric of $2 \mathrm{~mm}$ diameter on the sides and a transparent plastic of $150 \mu \mathrm{m}$ in the roof. The climate of the region has been characterized by Thornthwaite's methodology as $\mathrm{B}_{2} \mathrm{rB}_{3}{ }^{\prime} \mathrm{a}^{\prime}$, a humid mesothermic climate with low water deficits (April, July and August) and a concentration of summer potential evapotranspiration of $33 \%$. The annual average air temperature is $20.3{ }^{\circ} \mathrm{C}$, and the annual average rainfall is $1428.4 \mathrm{~mm}$ (Cunha and Martins 2009). The soil of the area has been classified as medium texture Neosol (Embrapa 2006).

The cultivar IAC 576-70 was used because it is the main cultivar of sweet cassava cultivated in the State of São Paulo; it occupies approximately $90 \%$ of the area, with high yields, excellent culinary qualities and architecture favourable to cultural practices (Otsubo and Lorenzi 2004).

The experiment was conducted in a completely randomized design that consisted of three evaluation periods [0, 45 and 90 days after water deficit (DAD)] and three soil water tensions $(-10,-40$ and $-70 \mathrm{kPa})$, with five replicates. The evaluation periods occurred during the development phase of the cassava branches and leaves, that is, the period from 90 to 180 days after planting (DAP) (Alves 2006), with 0, 45 and 90 DAD corresponding to 90,135 and $180 \mathrm{DAP}$, respectively. A soil water tension of $-10 \mathrm{kPa}$ was considered as the control, a tension of $-40 \mathrm{kPa}$ as a moderate water deficit and a tension of $-70 \mathrm{kPa}$ as a severe water deficit.

The planting occurred on November 13, 2014 using branches removed from the middle third of healthy plants aged 12 months. The branches were sectioned at right angles with the aid of a machete, which produced a seedbed of $0.20 \mathrm{~m}$ in length with 5-7 nodes. A seedbed of $1.00 \times 1.00 \times 0.57 \mathrm{~m}$ was planted per pot that contained approximately $0.30 \mathrm{~m}^{3}$ of soil and allowed the drainage of water.

Puncture tensiometers were installed close to the plant in all the pots at $20 \mathrm{~cm}$ of soil depth, and the tension was measured by a digital tensimeter (SondaTerra, São Paulo, Brazil). The plants were inspected and irrigated daily, and soil moisture was maintained at field capacity until the start of the treatments.

The chemical analysis of the soil was run at $0-20 \mathrm{~cm}$ depth before the experiment was set up. However, there was no need for fertilization at planting; cover fertilization was performed at 40 DAP with urea at a dose of $40 \mathrm{~kg} \mathrm{ha}^{-1}$ of $\mathrm{N}$ (Lorenzi et al. 1997). Thinning of the stems of the plants was performed at 45 DAP, which resulted in a standard of two stems per pot.

\section{Application of treatments and crop management}

The cassava plants were submitted to soil water tensions of $-10,-40$ and $-70 \mathrm{kPa}$ from $90 \mathrm{DAP}$ up to $180 \mathrm{DAP}$. The readings in the tensimeter were taken between $4 \mathrm{PM}$ and $5 \mathrm{PM}$ and were converted into soil water potential $(\Psi \mathrm{m})$ in units of $\mathrm{kPa}$ (Dourado Neto et al. 1995); the data were adjusted according to the soil water retention curve (Fig. 1) using the model described by Van Genutchen (1980).

The estimation of the irrigation layer was performed based on the available water capacity (AWC) and aimed to

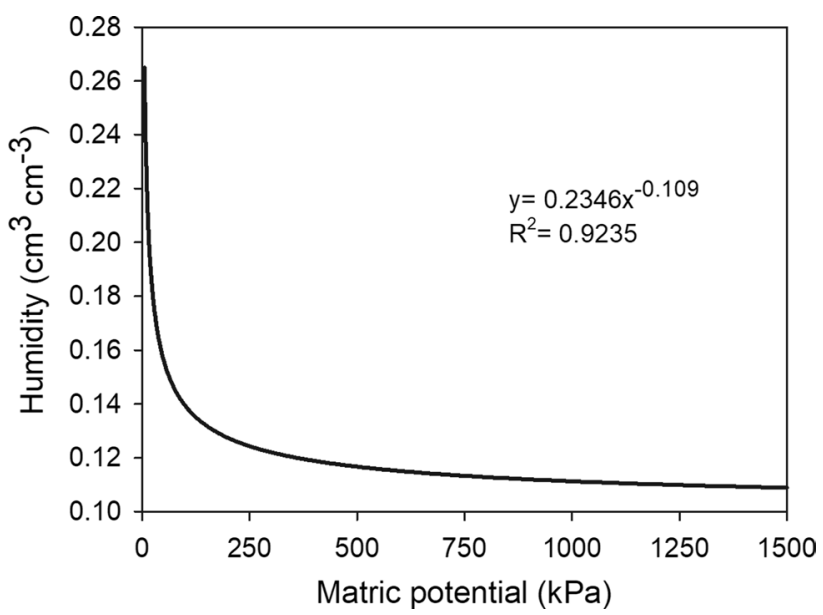

Fig. 1 Soil water retention curve of the experimental area for depths from 0 to $20 \mathrm{~cm}$ 
maintain the soil water tension in each treatment according to Eq. (1):

$\mathrm{AWC}=(\mathrm{FC}-\mathrm{PWP}) \times R$

where AWC is the available water capacity in the soil (mm), FC is the volumetric water content in the field capacity $\left(\mathrm{cm}^{3} \mathrm{~cm}^{-3}\right)$, PMP is the volumetric water content at the permanent wilting point $\left(\mathrm{cm}^{3} \mathrm{~cm}^{-3}\right)$ and $R$ is the effective depth of the root system $(\mathrm{mm})$ (considered $200 \mathrm{~mm}$ ).

The meteorological data within the protected environment were recorded in the experimental period by a data logger (Instrutherm, HT-500, São Paulo, Brazil) that obtained the temperature $\left({ }^{\circ} \mathrm{C}\right)$ and the relative humidity $(\%)$ of the air. The vapour pressure deficit (VPD) of the air was then calculated (Smith et al. 1991).

\section{Physiological variables}

The photosynthetic pigments (chlorophyll $a, b$ and carotenoids), stomatal density, water potential, relative water content, electrolyte leakage and chlorophyll $a$ fluorescence were evaluated on leaves at 0,45 and 90 DAD.

\section{Photosynthetic pigments}

The photosynthetic pigments were quantified in fresh leaf tissues by extraction in a solution of $N, N$-dimethylformamide (DMF) and subsequent determination by spectrophotometry. Leaf discs of $1.1 \mathrm{~cm}$ diameter were removed from the leaves located in the middle third of the cassava plants and placed in test tubes wrapped in aluminium foil with a screw cap containing $2 \mathrm{~mL}$ of DMF. The pigment contents were determined after $24 \mathrm{~h}$, and $1 \mathrm{~mL}$ of the extract was then taken and diluted in $1 \mathrm{~mL}$ of deionized water for spectrophotometry (Shimadzu, UV-2700, Kyoto, Japan) at wavelengths of $664 \mathrm{~nm}$ for chlorophyll $a, 647 \mathrm{~nm}$ for chlorophyll $b$ and $480 \mathrm{~nm}$ for carotenoids (Porra et al. 1989; Wellburn 1994).

\section{Stomatal density}

The stomatal density was determined in the same leaves that were removed to analyse the photosynthetic pigments by impression of the leaves using colourless nail polish and transparent adhesive tape. The number of stomata was obtained by the average count from two impressions of the abaxial surface of the leaf; an area of $0.0744 \mathrm{~mm}^{2}$ with $40 \times$ magnification was considered in a biological microscope (Biovideo, BEL Photonics, Monza, Italy). The stomatal density was estimated by the number of stomata $\mathrm{mm}^{-2}$ (Majumdar et al. 1972).

\section{Water potential and relative water content}

The leaf water potential $\left(\Psi_{\mathrm{w}}\right)$ was determined in the second expanded leaf removed from the apex of the cassava plants between 5 and 7 AM (predawn) using a Scholander pressure chamber (SoilMoisture Equipment, Santa Barbara, CA, USA). The readings were determined when exudation occurred from the cutting performed on the leaf petiole.

The leaf relative water content was obtained by determining on a precision analytical scale the masses of fresh, turgid and dry matter of six leaf discs of $1.1 \mathrm{~cm}$ diameter removed from the middle third of the cassava plants. The values of the masses were input to Eq. (2) (Barrs and Weatherley 1962):

$\mathrm{RWC}=(\mathrm{Mf}-\mathrm{Ms}) /(\mathrm{Mt}-\mathrm{Ms}) \times 100$

where RWC is the relative water content (\%), Mf is the fresh matter mass of the leaf discs ( $\mathrm{g})$, Ms is the dry matter mass of the leaf discs $(\mathrm{g})$ and $\mathrm{Mt}$ is the mass of the turgid matter of the leaf discs $(\mathrm{g})$.

\section{Electrolyte leakage}

The integrity of the cell membranes was determined by removing 30 leaf discs of $0.5 \mathrm{~cm}$ diameter from the middle third of the cassava plants, which were kept under agitation for $24 \mathrm{~h}$ in $10 \mathrm{~mL}$ of $0.3 \mathrm{M}$ solution of mannitol. At the end of the incubation, the electrical conductivity of the solution was measured by a digital conductivity meter. The tubes containing the solution and the leaf discs were then weighed and heated to boiling for $10 \mathrm{~min}$. After cooling, the tubes were again weighed, the difference of the evaporated volume was replaced with deionized water and the tubes were agitated for another $30 \mathrm{~min}$. The electrical conductivity was read again after the 30-min period and the electrolyte leakage was calculated by Eq. (3) (Lafuente et al. 1991):

$\mathrm{EL}=(\mathrm{Ci} / \mathrm{Cf}) \times 100$

where $\mathrm{EL}$ is the electrolyte leakage (\%), $\mathrm{Ci}$ is the initial electrical conductivity $\left(\mu \mathrm{S} \mathrm{cm}{ }^{-1}\right)$ and $\mathrm{Cf}$ is the final electrical conductivity $\left(\mu \mathrm{S} \mathrm{cm} \mathrm{cm}^{-1}\right)$.

\section{Chlorophyll $a$ fluorescence}

The emission of chlorophyll $a$ fluorescence was evaluated using a portable light modulated fluorometer (Opti-Sciences, OS5p, Hudson, USA) from the initial fluorescence $\left(F_{0}\right)$, maximum fluorescence $\left(F_{\mathrm{m}}\right)$ and variable fluorescence $\left(F_{\mathrm{v}}\right)$. The evaluations were performed at $9 \mathrm{AM}$ (the time the plants were adapted to the environment with photosynthetically active radiation, PAR, approximately $1500 \mu \mathrm{mol} \mathrm{m} \mathrm{m}^{-2}$ $\left.\mathrm{s}^{-1}\right)$. The effective quantum efficiency of photosystem II $\left(\Delta F / F_{\mathrm{m}}{ }^{\prime}\right)$, the electron transport rate $(\mathrm{ETR})$ and the potential 
quantum efficiency of photosystem II $\left(F_{\mathrm{v}} / F_{\mathrm{m}}\right)$ were analysed, the last being obtained after the leaves were allowed to adapt to the dark for $\sim 20$ min with the use of leaf clips and just after a saturating light flash of $0.5 \mathrm{~s}$ duration. All readings were standardized on the third expanded leaf of the plant from the apex, and an average of two readings in each plant was obtained.

\section{Statistical analysis}

Data were submitted to analysis of variance by the $\mathrm{F}$ test with subsequent comparison of means using the Tukey test ( $p \leq 0.05$ ) using the statistics program SISVAR (Variance Analysis System, version 5.0, Lavras, Brazil) (Ferreira 2008). Data were analyzed in a split plot in a time arrangement, considering the plot as the evaluation period and the split plot as the soil water tension. When there was no interaction between the factors under study, the data were evaluated separately.

\section{Results}

\section{Environmental conditions during the experiment}

The air temperature within the protected crop during the experiment ranged from 21.0 to $33.3{ }^{\circ} \mathrm{C}$, with an average of $23.5^{\circ} \mathrm{C}$ in the period from 90 to $180 \mathrm{DAP}$. The relative humidity of the air averaged $67.2 \%$; however, the humidity was higher $(73.9 \%)$ in the development phase of the branches and leaves of the cassava (90-180 DAP) (Fig. 2a). The increase of the relative humidity of the air in this phase and the consequent decrease in temperature directly contributed to the reduced VPD of the air, which ranged from 0.6 to $1.0 \mathrm{kPa}$. The VPD reached an average of $2.4 \mathrm{kPa}$ at 45 DAP (Fig. 2b).

From 90 to 180 DAP, the IAC 576-70 sweet cassava plants were irrigated daily to maintain the soil water tension in each treatment. The tensions before irrigation during this period were $-17.6 \mathrm{kPa}$ in the treatment of $-10,-48.9 \mathrm{kPa}$ in the treatment of -40 and $-65.3 \mathrm{kPa}$ in the treatment of $-70 \mathrm{kPa}$. The soils took approximately 15 days after the start of the treatments to reach the soil water tensions of -40 and $-70 \mathrm{kPa}$, which were maintained until the end of the experiment (Fig. 2c).

\section{Physiological analyses}

At the start of the treatments, when all cassava plants were under a soil water tension of approximately $-10 \mathrm{kPa}$, the chlorophyll $a$ contents were on average $11.18 \mu \mathrm{g} \mathrm{cm}$ (Fig. 3a). There was no significant difference between the plants under -10 and $-40 \mathrm{kPa}$ at $45 \mathrm{DAD}$; however, plants
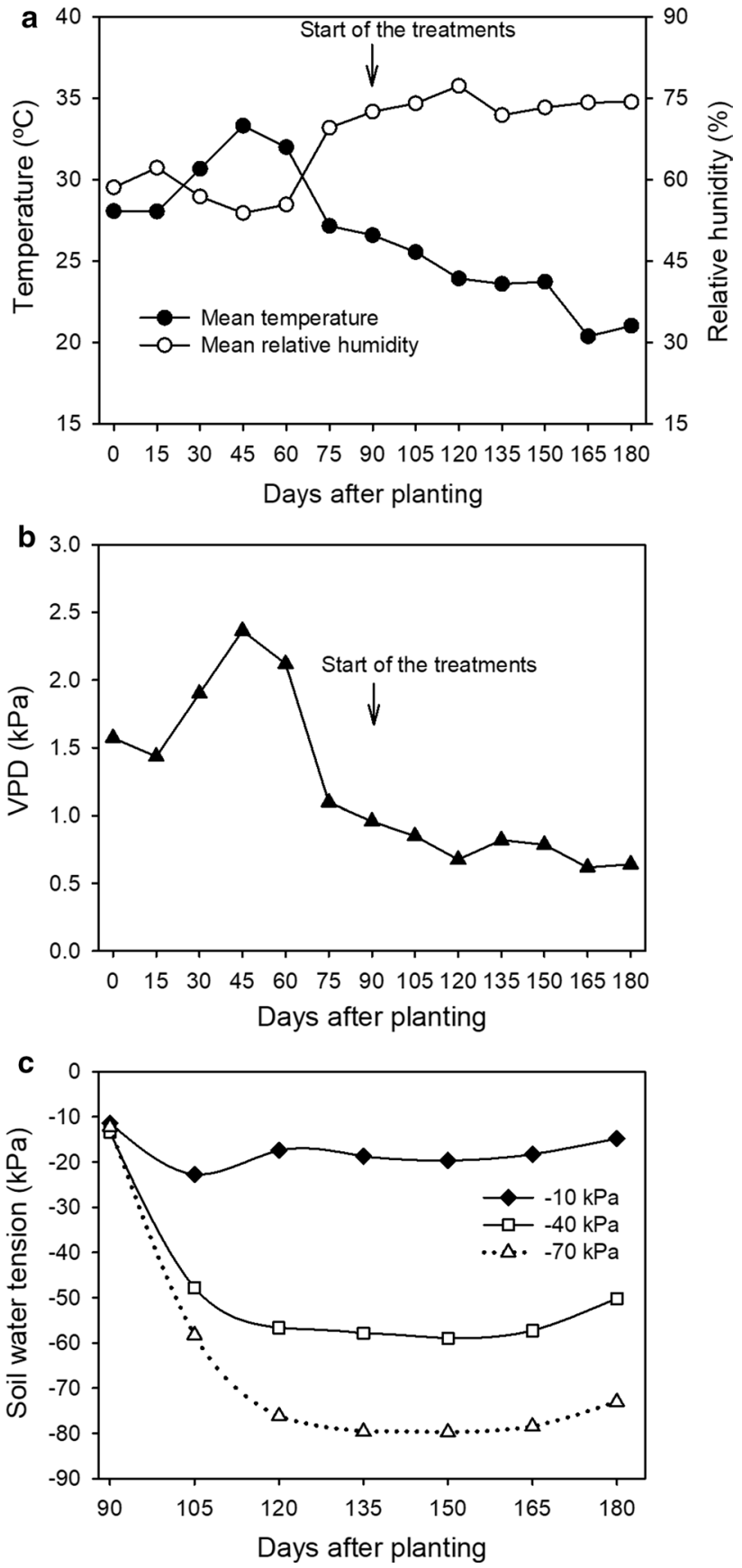

Fig. 2 Biweekly temperature and relative humidity (a), vapour pressure deficit (b) and soil water tension in the experimental period (c) during the development phase of the branches and leaves of the sweet cassava IAC 576-70

under - $70 \mathrm{kPa}$ showed $18.87 \mu \mathrm{g} \mathrm{cm} \mathrm{cm}^{-2}$ of chlorophyll $a$, an increase of $50.4 \%$ in relation to plants under a tension of $-10 \mathrm{kPa}$ in the same period. There was no significant difference in the chlorophyll $a$ levels of cassava plants independent of soil water tension at 90 DAD. In general, plants under $-10 \mathrm{kPa}$ maintained average chlorophyll $a$ levels of $11.88 \mu \mathrm{g} \mathrm{cm}^{-2}$ during the development phase of the 

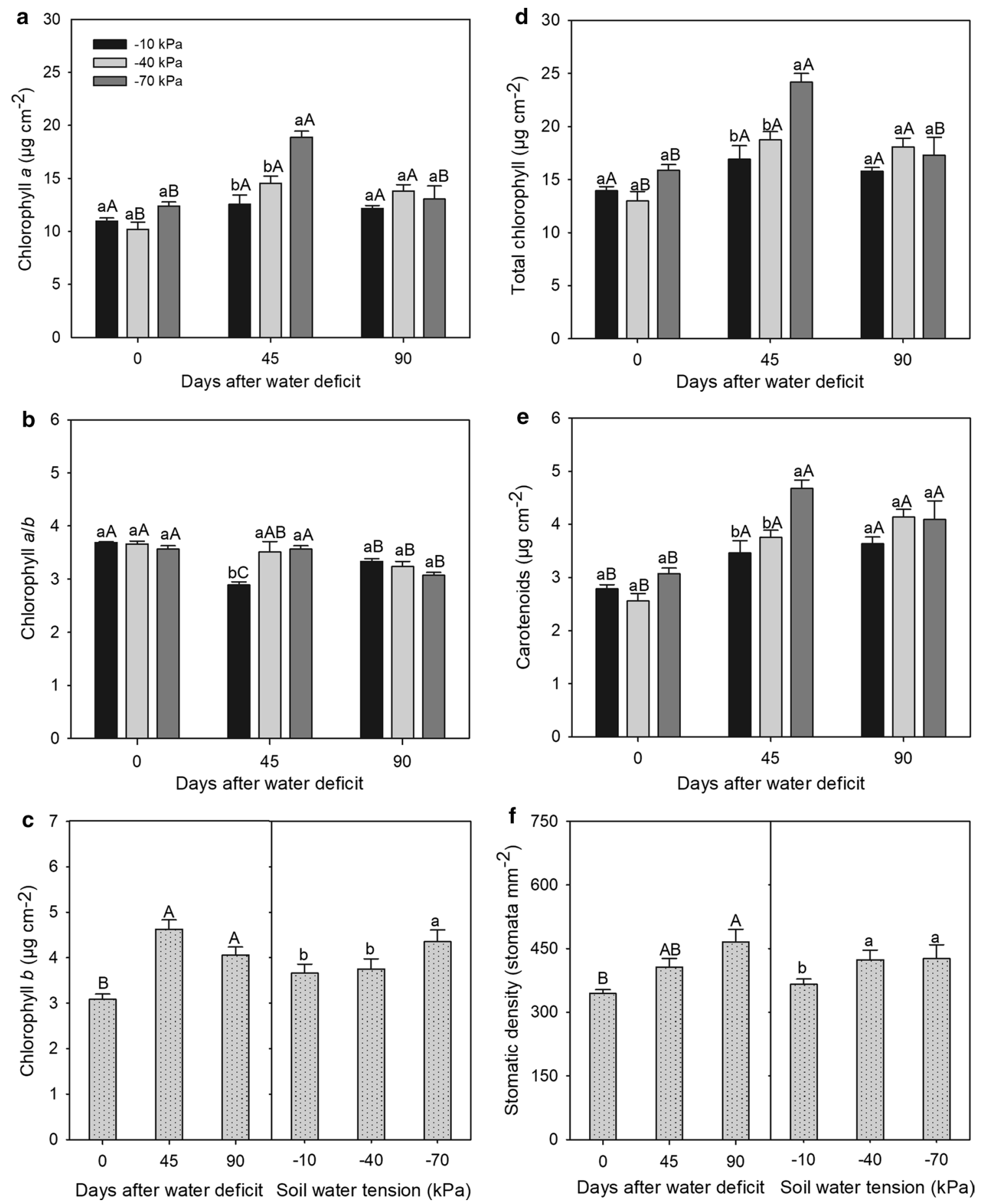

Fig. 3 Chlorophyll $a$ (a), chlorophyll $a / b$ (b), chlorophyll $b$ (c), total chlorophyll $(a+b)(\mathbf{d})$, carotenoids $(\mathbf{e})$ and stomatal density of the foliar abaxial surface (f) in IAC 576-70 sweet cassava plants under different soil water tensions during the development phase of the

branches and leaves, whereas the plants under tension of - $40 \mathrm{kPa}$ had an increase of $42.5 \%$ at $45 \mathrm{DAD}$ and an average of $14.17 \mu \mathrm{g} \mathrm{cm}^{-2}$ chlorophyll $a$ between 45 and 90 DAD. Plants under a tension of $-70 \mathrm{kPa}$ increased $52.3 \%$ at 45

branches and leaves. Means followed by the same capital letter for the days and lowercase letter for the tensions did not differ based on the Tukey test $(p \leq 0.05)$. The bars indicate the standard error of the mean of five replicates

DAD relative to the plants at the start of the treatments, with a reduction of $30.8 \%$ in chlorophyll $a$ content at 90 DAD.

The chlorophyll $a / b$ ratio of cassava plants averaged 3.64 at 0 DAD (Fig. 3b). Plants under a tension of $-10 \mathrm{kPa}$ had a 
lower chlorophyll $a / b(2.88)$ ratio at $45 \mathrm{DAD}$, which differed from other plants under tensions of -40 and $-70 \mathrm{kPa}$ and indicates that they had higher levels of chlorophyll $b$ in their leaves. There was no significant difference between plants at different soil water tensions at $90 \mathrm{DAD}$. The chlorophyll $a / b$ ratios of plants under a tension of $-10 \mathrm{kPa}$ fluctuated during the experimental period, with significant differences between the days after the water deficit. Plants under tensions of -40 and $-70 \mathrm{kPa}$ had a decrease in chlorophyll $a / b$ ratio between 0 and $90 \mathrm{DAD}$.

The levels of chlorophyll $b$ in the leaves showed no interaction between the DAD and soil water tension (TS) factors $(F=1.75 ; p=0.17)$. The contents increased during the development phase of the branches and leaves of the cassava plants regardless of the soil water tension applied, with a mean of $4.62 \mu \mathrm{g} \mathrm{cm}^{-2}$ chlorophyll $b$ at 45 DAD and $4.06 \mu \mathrm{g} \mathrm{cm}^{-2}$ at $90 \mathrm{DAD}$. In general, the plants under a tension of $-70 \mathrm{kPa}$ presented a chlorophyll $b$ increment of $18.8 \%$ in relation to the plants under a soil water tension of $-10 \mathrm{kPa}$ (Fig. 3c).

The total chlorophyll content did not significantly differ among the cassava plants at 0 DAD; the average was $14.27 \mu \mathrm{g} \mathrm{cm}^{-2}$ (Fig. 3d). At $45 \mathrm{DAD}$, the plants submitted to a tension of $-70 \mathrm{kPa}$ had total chlorophyll contents of $24.17 \mu \mathrm{g} \mathrm{cm}^{-2}$, an increase of 42.9 and $29.1 \%$ in relation to plants under tensions of -10 and $-40 \mathrm{kPa}$, respectively, with significant differences between the tensions. The plants had the same total chlorophyll content, a mean of $17.05 \mu \mathrm{g} \mathrm{cm}^{-2}$, at $90 \mathrm{DAD}$ regardless of the soil water condition. Plants under a tension of $-10 \mathrm{kPa}$ maintained total chlorophyll contents of approximately $15.55 \mu \mathrm{g} \mathrm{cm}^{-2}$ during the development phase of the branches and leaves, whereas plants under a tension of $-40 \mathrm{kPa}$ showed an increase of $44.1 \%$ at $45 \mathrm{DAD}$ in relation to the beginning of the treatments and did not differ from the plants in the same tension at $90 \mathrm{DAD}$. Plants under a tension of $-70 \mathrm{kPa}$ had a decrease of $28.4 \%$ in total chlorophyll content at $90 \mathrm{DAD}$ in relation to $45 \mathrm{DAD}$.

The carotenoid content of cassava plants at $0 \mathrm{DAD}$ was on average $2.80 \mu \mathrm{g} \mathrm{cm}^{-2}$ (Fig. 3e). The plants under a tension of $-70 \mathrm{kPa}$ had average carotenoid levels of approximately $4.67 \mu \mathrm{g} \mathrm{cm}^{-2}$ at $45 \mathrm{DAD}, 35.3 \%$ higher than the plants under a tension of $-10 \mathrm{kPa}$, which significantly differed from this case and the plants under a tension of $-40 \mathrm{kPa}$. There was no significant difference of the plants in the different tensions at $90 \mathrm{DAD}$. All plants presented increase of carotenoid contents between 0 and $90 \mathrm{DAD}$; at the end of the experimental period, $3.63 \mu \mathrm{g} \mathrm{cm}^{-2}$ was obtained in the plants under a tension of $-10 \mathrm{kPa}, 4.13 \mu \mathrm{g} \mathrm{cm}^{-2}$ in the plants under a tension of $-40 \mathrm{kPa}$ and $4.08 \mu \mathrm{g} \mathrm{cm}^{-2}$ in plants under a tension of $-70 \mathrm{kPa}$.

The stomatal density of the abaxial surface of the cassava leaf varied from 344.08 to 465.95 stomata $\mathrm{mm}^{-2}$ during the development phase of the branches and leaves regardless of the soil water condition. However, the water deficiency caused by soil water tensions of -40 and - $70 \mathrm{kPa}$ stimulated a $16.0 \%$ increase in leaf stomatal density (Fig. 3f). There was no interaction between the DAD and TS factors in the stomatal density variable $(F=2.07$; $p=0.11$ ).

The impression of the abaxial surface of the cassava leaf verified at 90 days of treatment under a soil water tension of $-10 \mathrm{kPa}$ demonstrated turgid and more spaced stomata, which evidenced the occurrence of a crown of papilliform cells around the stomata (Fig. 4a). The plants under a tension of $-40 \mathrm{kPa}$ presented partially open stomata and greater counts (Fig. 4b). The tension of $-70 \mathrm{kPa}$ stimulated the closure of the stomata in the leaves and the production of smaller stomata with less spacing between them (Fig. 4c).

The interaction between the DAD and TS factors did not occur in the physiological variables of water potential $(F=1.28 ; p=0.30)$, relative water content $(F=1.26$; $p=0.31)$, electrolyte leakage $(F=1.83 ; p=0.15)$, potential quantum efficiency of photosystem II $(F=0.01 ; p=0.99)$, effective quantum efficiency of photosystem II $(F=1.04$; $p=0.40)$ and electron transport rate $(F=2.34 ; p=0.08)$.

The water potential (Fig. 5a) and relative water content (Fig. 5b) in the leaves diminished to 90 DAD independent of soil water status and showed a decrease of $48.2 \%$ in water potential and $8.5 \%$ in relative water content between 45 and 90 DAD. The different soil water tensions did not interfere in the water potential and the relative water content of the plants, which were maintained throughout the experimental period at approximately $-0.25 \mathrm{MPa}$ and $87.31 \%$, respectively.

The electrolyte leakage in the development phase of the branches and leaves ranged from 29.39 to $26.33 \%$, with no significant difference between DAD. Plants under the tensions of $-10,-40$ and $-70 \mathrm{kPa}$ had similar electrolyte leakage (Fig. 5c).

The potential quantum efficiency of photosystem II of the plants was on average 0.75 , independent of soil water tension. There was no difference between the plants subjected to different tensions (Fig. 5d). However, the effective quantum efficiency of photosystem II of the plants oscillated during the study phase, with a reduction of $57.4 \%$ at 45 DAD and an increase of $34.0 \%$ at $90 \mathrm{DAD}$. The plants under the tensions of -40 and $-70 \mathrm{kPa}$ had the effective quantum efficiency of photosystem II reduced by $13.3 \%$ because of water deficiencies (Fig. 5e).

The electron transport rate at 45 DAD was $90.43 \mu \mathrm{mol} \mathrm{m} \mathrm{s}^{-1}$, with an increase of $48.0 \%$ at $90 \mathrm{DAD}$ (Fig. 5f). In general, lower soil water tensions ( -40 and $-70 \mathrm{kPa}$ ) caused a $16.2 \%$ reduction in the electron transport rate of cassava plants. 

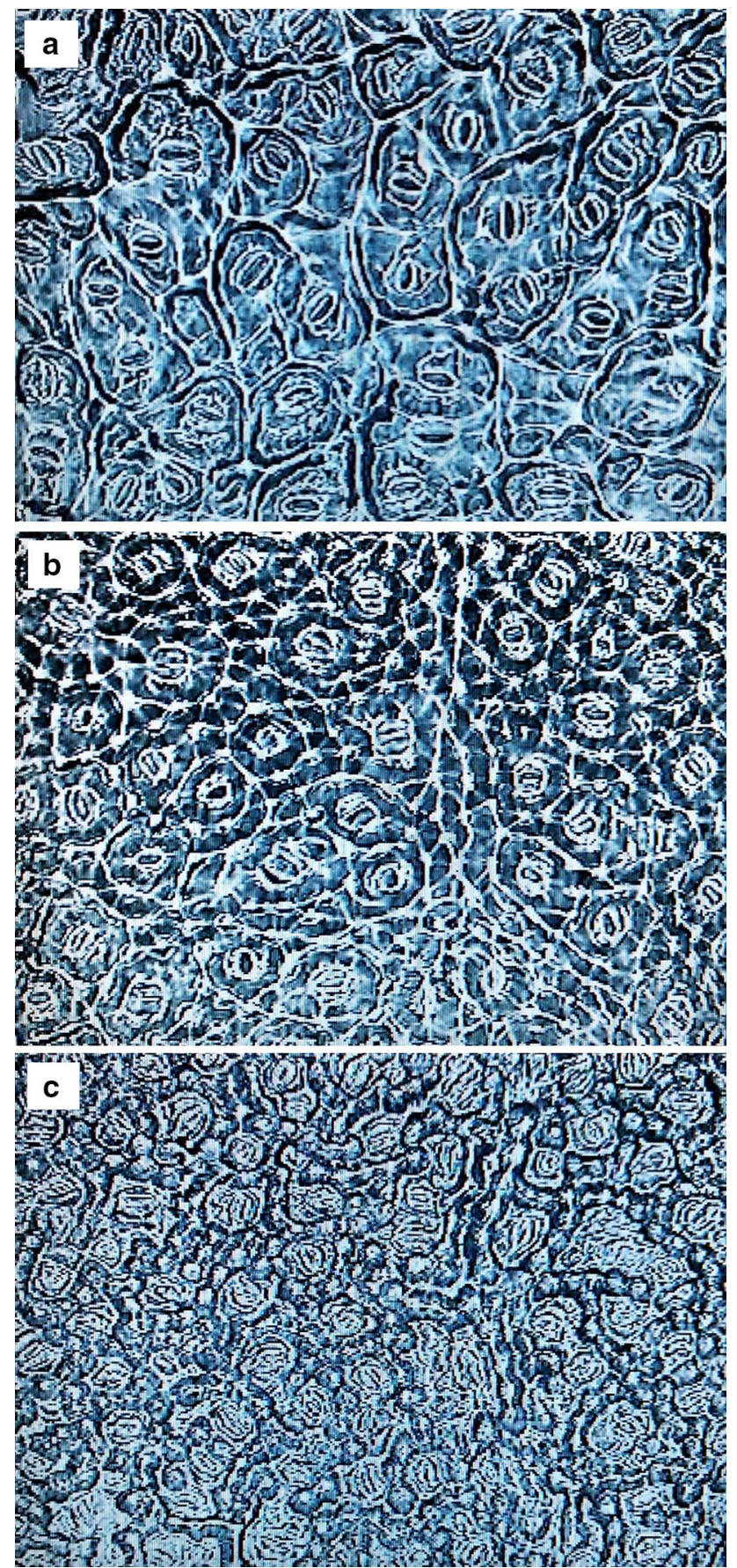

Fig. 4 Printing of the abaxial surface of the leaf in an area of $0.0744 \mathrm{~mm}^{2}$ at 90 days of treatment under soil water tensions of - $10 \mathrm{kPa}(\mathbf{a}),-40 \mathrm{kPa}(\mathbf{b})$ and $-70 \mathrm{kPa}(\mathbf{c})$ in IAC 576-70 sweet cassava plants during the development phase of the branches and leaves

\section{Discussion}

The growth and production of cassava are favoured by average annual temperatures above $20^{\circ} \mathrm{C}$ (El-Sharkawy 2003) and air humidities between 60 and 70\% (Abreu et al. 2008).
The temperature and the relative humidity of the air inside the protected crop during the experimental phase were in the ideal range for the culture (Fig. 2a). Cassava plants are very sensitive to changes in atmospheric conditions. When exposed to dry air, the stomata rapidly close, reducing transpiration in VPD above $2 \mathrm{kPa}$. This mechanism of avoidance to stress maximizes the water use efficiency of photosynthesis, particularly under soil water deficiency, which is an advantage compared with less sensitive species such as maize (El-Sharkawy 2012).

Soil water tensions applied in the treatments of -40 and - $70 \mathrm{kPa}$ during the development phase of the branches and leaves of the sweet cassava IAC 576-70 (Fig. 2c) were reached approximately 15 days after the start of the treatments, which may have interfered in the physiological evaluations of the plants at 45 and 90 DAD because the water-deficit period corresponded to 30 and 75 DAD in these treatments, respectively.

The first response of plants to water deficiency is the reduction of stomatal conductance, which avoids loss of water to the atmosphere (Guo et al. 2010). However, the closure of the stomata has complex consequences that require adjustments in photosynthesis, respiration, nutrients and water flow (Bohnert and Jensen 1996). Photosynthesis is one of the main processes most affected by abiotic stress (Liu and Huang 2008).

Photosynthetic pigments are responsible for the capture of light energy and its conversion into chemical energy in the initial stages of photosynthesis. Chlorophyll $a$ and $b$ and carotenoids are located on the membranes of thylakoids in chloroplasts and constitute the most abundant natural pigment group present in plants (Taiz and Zeiger 2013). Chlorophylls are easily degraded because they have a chemically unstable structure (Streit et al. 2005). Therefore, photosynthetic pigments can be affected when a plant is subjected to dry conditions and can decrease the efficiency of light energy absorption, electron transfer and the production of ATP and NADPH in the photochemical phase of photosynthesis. Environmental factors such as water deficiency, luminosity, thermal changes, high levels of ethylene or a combination of factors may influence the degradation of chlorophyll (Heaton and Marangoni 1996).

A decrease in chlorophyll content when plants are subjected to water deficiency has been observed in diverse cultures such as wheat (Zaefyzadeh et al. 2009), sugarcane (Silva et al. 2013), sunflower (Manivannan et al. 2014), cotton (Shah et al. 2011) and maize (Miri and Armin 2013). However, in the present study, chlorophyll $a$ and total chlorophyll content increased in plants under the lowest tension $(-70 \mathrm{kPa})$, mainly at $45 \mathrm{DAD}$ (Fig. 3a, d). This may have been a response of the acclimatization of cassava plants to water deficiency since the stomatal sensitivity of the crop is changed according to the climate and water in the soil 

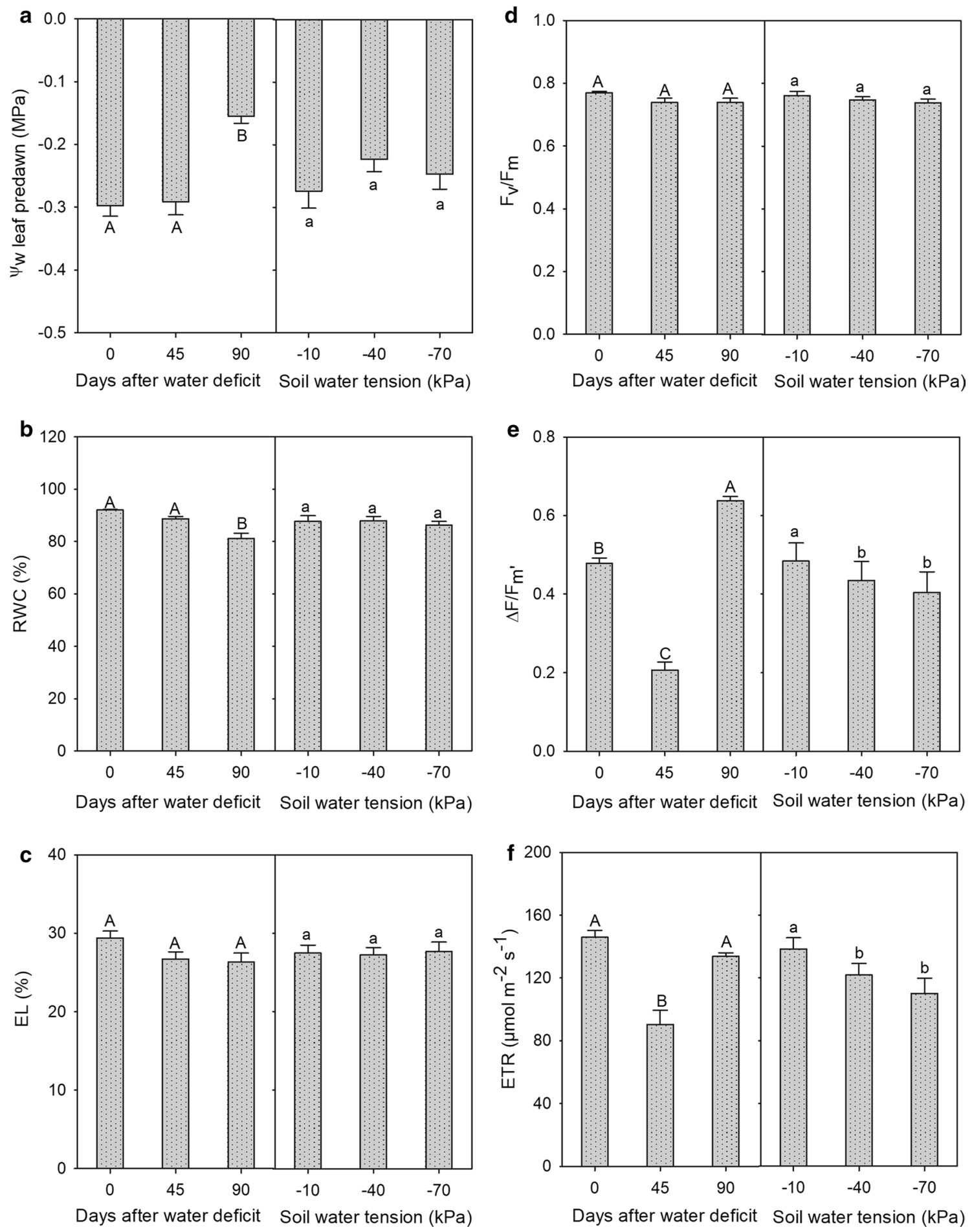

Fig. 5 Leaf water potential (a), relative water content (b), electrolyte leakage (c), potential quantum efficiency of photosystem II (d), effective quantum efficiency of photosystem II (e) and electron transport rate (f) in IAC 576-70 sweet cassava plants under different soil water tensions during the development phase of the branches and leaves.

Means followed by the same capital letter for the days and lowercase letter for the tensions did not differ based on the Tukey test $(p \leq 0.05)$. The bars indicate the standard error of the mean of five replicates 
(El-Sharkawy 1993) and combines the heliotropic response of the leaves by folding them in the hottest hours of the day and opening them only when the VPD is smaller and the radiation is low (Calatayud et al. 2000), which could make photosynthesis difficult for most of the day. In addition to the verified foliar folding of the plants in the cultivar under study, the increase in chlorophyll content probably contributed to the more efficient absorption of the radiation when the stomatal conductance was higher.

Berg et al. (1986) studied cassava cultivated in the field and verified that the foliar folding phenomenon decreased leaf light interception by $50 \%$ and reduced leaf temperature from 6 to $7^{\circ} \mathrm{C}$ and the VPD between leaf and air by $1.3 \mathrm{kPa}$ while increasing the stomatal conductance twice as much as in leaves that remained horizontal. Therefore, leaf folding or falls at noon in irrigated or water-deficient plants may act as a mechanism to avoid water stress, conferring on cassava a prolonged drought tolerance response (El-Sharkawy 2004).

Carotenoids in photosynthetic tissues are protective pigments for chlorophyll protection against photooxidation (Bartley and Scolnik 1995). Cassava plants under a tension of $-70 \mathrm{kPa}$ showed an increase in carotenoid contents at 45 DAD (Fig. 3e), which would certainly improve the dissipation of excess light energy in the antenna complex that was not being used in the photochemical phase of photosynthesis because of soil water deficiency. Pompelli et al. (2010) found an increase in the carotenoid contents in jatropha plants at 4 and 8 days of water deficit. Lin et al. (2006) studied sweet potato plants and did not observe differences in carotenoid contents between plants in control and water deficit at 14 days of treatment. In sugarcane, there was a decrease in carotenoid contents in plants submitted to 15 days of water deficit, but there were differences between cultivars (Santos et al. 2015). In rice, the decrease in carotenoids was reported by Usman et al. (2013). This suggests a great variability in crop behavior, since the responses to water deficiency depend on the interaction of several factors related to the plant and the environment.

Stomatal density is an important echo physiological parameter that affects gas exchange and photosynthesis (Camargo and Marenco 2011). Most of the cassava cultivars have many stomata on the abaxial leaf surface $\left(300-500 \mathrm{~mm}^{-2}\right)$ and practically none on the adaxial surface (El-Sharkawy et al. 1984). The abaxial surface of the cassava leaves has an epidermis with papilliform cells that add approximately $15 \%$ to the thickness of the leaf and increase the resistance to flow to the atmosphere by two to three times, which contributes to the conservation of water in the leaf while assimilating the $\mathrm{CO}_{2}$ (Angelov et al. 1993).

Several cassava cultivars show plasticity in leaf anatomy and differences in stomatal characteristics, such as density, that can demonstrate potential cultivars for drought tolerance (Cerqueira 1992; El-Sharkawy 2006). The reduction in the size of the stomata is an important event in the regulation of gas exchange since leaves with smaller stomata present a greater water use efficiency because they present a smaller size of the stomatal pores, thus conditioning a lower water loss through transpiration (Lake et al. 2001; Boeger and Wisniewski 2003). The tensions of -40 and - $70 \mathrm{kPa}$ promoted an increase in stomatal density on the abaxial surface of IAC 576-70 cassava leaves, which may be a response of acclimatization or adaptation of the plant to tolerate soil water deficiency. Other crops show foliar plasticity to changes of soil moisture status and dynamics. In potato, a reduction in leaf stomatal density was observed under severe water deficit, while under moderate water deficit, there were smaller and denser stomata production favoring gas exchange and optimization of water use efficiency (Sun et al. 2014). In maize, there was a significant increase in leaf stomatal density with soil water reduction, accompanied by decreased transpiration and net photosynthetic rate (Zhao et al. 2015). In wheat plants, the reduction of leaf stomatal density under water-deficit conditions was the main cause of increase in water use efficiency (Li et al. 2017). Changes in stomatal characteristics are associated by many authors, mainly regarding size and density, the adjustment of stomatal opening for better water use efficiency in response to atmospheric conditions (Yan et al. 2012; Egea et al. 2011; Zhang et al. 2006).

The water potential and the relative water content in the leaves are important characteristics that influence the water relations of the plants (Anjum et al. 2011). ElSharkawy (2012) evaluated the response of cassava plants to environmental conditions and verified that stomata closure protected the leaf against dehydration without any changes in leaf water potential in plants with and without water deficiency. Tafur et al. (1997) did not observe significant differences in the water potential of cassava plants submitted to water deficiency and soil fertilization; they explained this result by stomatal closure and the ability of the plant to absorb water from the deep layers of the soil. In this study, cassava plants maintained the water potential and the relative water content unchanged in the predawn between plants under different soil water tensions (Fig. 5a, b). Alves and Setter (2004) studied cassava plants under water deficiency and concluded that the tolerance of the crop to drought can be attributed to the maintenance of the high-water potential of the tissues during the stress phase. Turyagyenda et al. (2013) investigated two cassava cultivars under 10 days of water deficit and verified differences in the relative water content of the leaves among the cultivars, although these did not differ from the plants in the control. In plants of tuberous roots such as sweet potato, maintenance of water potential in the tissues in adaptive response to drought has also been observed (Motsa et al. 2015). In tuber plants such as potato, the decrease stomatal 
conductance occurs in parallel with the leaf water potential as a water conserving strategy (Obidiegwu et al. 2015). In bean, a similar result occurred with the imposition of the water deficit, with reductions in leaf water potential and stomatal conductance and consequent increase in intrinsic water use efficiency (Dias and Brüggemann 2010). However, maintaining cell turgescence has been attributed as a possible mechanism that confers drought tolerance on soybean (Ku et al. 2013; Bellaloui et al. 2013).

Cell membranes of leaf tissues are the first targets of many abiotic stresses (Levitt 1980). The extravasation of electrolytes in leaf fragments has been widely used as an estimate of injury caused by stresses in various cultures (Bajji et al. 2002; Zhao et al. 2009). Cassava plants showed cell membrane integrity independent of soil water status (Fig. 5c). Maintenance of membrane stability during severe water deficit is important to continue the physiological metabolism under low water potential (Tripathy et al. 2000). Faria et al. (2013) analyzed castor plants under water deficiency and observed that the extravasation of electrolytes differed between cultivars. A similar result was found in potato plants (Rudack et al. 2017). Differences in membrane integrity may be due to cell-wall properties and leaf structure (Kocheva et al. 2014). Wedeking et al. (2017) studied sugar beet under drought conditions and observed highly significant exponential correlations between temperature variation $\Delta T_{\text {air-leaf }}$ and membrane stability and leaf water status. Membrane injury index can be used as a useful parameter to select droughttolerant genotypes (Ulemale et al. 2013).

The photosynthetic activity of plants can be evaluated by the analysis of chlorophyll $a$ fluorescence. The potential quantum efficiency is presented by the $F_{\mathrm{v}} / F_{\mathrm{m}}$ ratio determined after dark adaptation, where $F_{\mathrm{m}}$ is the maximum fluorescence and $F_{\mathrm{v}}$ is the variable fluorescence obtained by the difference between $F_{\mathrm{m}}$ and $F_{0} . F_{0}$ refers to the initial fluorescence, corresponding to the emission of light by the excited chlorophyll molecules, before the energy is transmitted to the reaction centre of photosystem II (Rascher et al. 2000). The $F_{\mathrm{v}} / F_{\mathrm{m}}$ ratio is used as a sensitive indicator of the photosynthetic performance of a plant and can range from 0.75 to 0.85 in vegetables under optimal environmental conditions. However, there is a decline in the potential quantum efficiency of photosystem II of a plant subjected to stressful environments, indicated by the fall in the ratio $F_{\mathrm{v}} / F_{\mathrm{m}}$ (Björkman and Powles 1984; Krause and Weis 1991).

The effective quantum efficiency of photosystem II described by the $\Delta F / F_{\mathrm{m}}{ }^{\prime}$ ratio, $\Delta F$ being the difference between the maximum fluorescence $\left(F_{\mathrm{m}}{ }^{\prime}\right)$ and the dynamic equilibrium state fluorescence $\left(F_{\mathrm{s}}\right)$, both in the presence of light (Marques and Silva 2008), reveals the effectiveness of the use of the radiation absorbed by the chlorophylls associated with photosystem II through the efficiency in the electron transport, considered as indicative of photosynthesis.
Cassava plants did not show a decline in the $F_{\mathrm{v}} / F_{\mathrm{m}}$ ratio when submitted to soil water deficiency (Fig. 5d), which indicates that the tensions of -40 and $-70 \mathrm{kPa}$ did not interfere in the maximum photosynthetic efficiency of the plants. On the other hand, the effective quantum efficiency of photosystem II and the electron transport rate of cassava plants were reduced under the lowest tensions (Fig. 5e, f). These changes were probably associated with photoinhibition because of super reduction of the electron acceptors in photosynthesis II (Foyer and Noctor 2000). An et al. (2015) researched the changes in chlorophyll fluorescence in cassava plants throughout the day and observed a positive correlation between the effective quantum efficiency of photosystem II and the rate of electron transport. Silva et al. (2010) evaluated the photosynthetic changes in jatropha plants caused by drought and heat and observed reductions of $56 \%$ in the effective quantum efficiency of photosystem II and $83 \%$ in the rate of electron transport; they did not present changes in the $F_{\mathrm{v}} / F_{\mathrm{m}}$ ratio. In sweet potato, chlorophyll degradation in the leaves caused by induced drought contributed significant reductions in the effective quantum efficiency of photosystem II and in the $F_{\mathrm{v}} / F_{\mathrm{m}}$ ratio at 3 and 4 months of treatment (Yooyongwech et al. 2017). In sugar beet, the efficiency of the photosynthetic apparatus declined under water-deficit conditions (Choluj et al. 2014).

From the results obtained, we conclude that a soil water tension of $-70 \mathrm{kPa}$ promotes an increase of the total chlorophyll content and carotenoids in IAC 576-70 sweet cassava plants at 45 days of water deficit. This cultivar can maintain a leaf water potential close to $-0.3 \mathrm{MPa}$ and a relative water content between 80 and $90 \%$ in the predawn and can maintain the integrity of cell membranes in the leaves and the potential quantum efficiency of photosystem II under soil water tensions of $-10,-40$ and $-70 \mathrm{kPa}$. Water deficiency impairs plant photosynthesis because of reductions in the effective quantum efficiency of photosystem II and the rate of electron transport; however, there is an increase of $16.0 \%$ in stomatal density in this stress condition.

Author contribution statement LFMP: set up and carried out the experiment, analyzed and interpreted the data, and prepared the manuscript. SZ: set up and carried out the experiment. MAS: planned and wrote the proposal, designed and supervised the experiment, interpreted the data, and was responsible for the manuscript revision.

Acknowledgements LFMP and SZ acknowledge the Coordination of Improvement of Higher Level Personnel (CAPES, Brazil) for scholarships granted during $\mathrm{PhD}$ and Master's degree courses, respectively, and MAS acknowledges the National Council for Scientific and Technological Development (CNPq, Brazil) for the "Productivity in Research" fellowship (Proc. 311255/2012-4). 


\section{References}

Abreu ML, Bicudo SJ, Brachtvogel EL, Curcelli F, Aguiar EB (2008) Interação genótipo ambiente na cultura da mandioca. Rev Raízes Amidos Trop 4:43-53

Alves AAC (2002) Cassava botany and physiology. In: Hillocks RJ, Thresh JM, Bellotti AC (eds) Cassava: biology, production and utilization. Cabi, Wallingford, pp 67-89

Alves AAC (2006) Fisiologia da mandioca. Aspectos socioeconômicos e agronômicos da mandioca. Embrapa, Cruz das Almas, pp 138-169

Alves AAC, Setter TL (2004) Abscisic acid accumulation and osmotic adjustment in cassava under water deficit. Environ Exp Bot $51: 259-271$

An F, Chen T, Li G, Zhang Z, Li K (2015) Diurnal changes in chlorophyll fluorescence of photosystem II in cassava cultivar SC8. Southwest China J Agric Sci 28:2469-2474

Angelov MN, Sun J, Byrd GT, Brown RH, Black CC (1993) Novel characteristics of cassava, Manihot esculenta Crantz, a reputed C3-C4 intermediate photosynthesis species. Photosynth Res 38:61-72

Anjum SA, Xie X, Wang L, Saleem MF, Man C, Lei W (2011) Morphological, physiological and biochemical responses of plants to drought stress. Afr J Agric Res 6:2026-2032

Bajji M, Kinet JM, Lutts S (2002) The use of the electrolyte leakage method for assessing cell membrane stability as a water stress tolerance test in durum wheat. Plant Growth Regul 36:61-70

Baret F, Houlès V, Guérif M (2007) Quantification of plant stress using remote sensing observations and crop models: the case of nitrogen management. J Exp Bot 58:869-880

Barrs HD, Weatherley PE (1962) A re-examination of the relative turgidity technique for estimating water deficit in leaves. Aust J Biol Sci 15:413-428

Bartley GE, Scolnik PA (1995) Plant carotenoids: pigments for photoprotection, visual attraction, and human health. Plant Cell 7:1027-1038

Bellaloui N, Gillen AM, Mengistu A, Kebede H, Fisher DK, Smith JR, Reddy KN (2013) Responses of nitrogen metabolism and seed nutrition to drought stress in soybean genotypes differing in slowwilting phenotype. Front Plant Sci 4:1-13

Berg VS, El-Sharkawy MA, Hernandez ADP, Cock JH (1986) Leaf orientation and water relations in cassava. Annual Meeting of the American Society of Plant Physiologists. Louisiana State University, Baton Rouge, pp 8-12

Björkman O, Powles SB (1984) Inhibition of photosynthetic reactions under water stress: interaction with light level. Planta 161:490-504

Boeger MRT, Wisniewski C (2003) Comparação da morfologia foliar de espécies arbóreas de três estádios sucessionais distintos de Floresta Ombrófila Densa (Floresta Atlântica) no sul do Brasil. Revista Brasil Bot 26:61-72

Bohnert HJ, Jensen RG (1996) Strategies for engineering water-stress tolerance in plants. Trends Biotechnol 14:89-97

Bray EA (1993) Molecular responses to water deficit. Plant Physiol 103:1035-1040

Calatayud PA, Llovera E, Bois JF, Lamaze T (2000) Photosynthesis in drought-adapted cassava. Photosynthetica 38:97-104

Camargo MAB, Marenco RA (2011) Density, size and distribution of stomata in 35 rainforest tree species in Central Amazonia. Acta Amaz 41:205-212

Cerqueira YM (1992) Efeito da deficiência de água na anatomia foliar de cultivares de mandioca Manihot esculenta Crantz. I-Densidade estomática. Sitientibus 10:103-115

Choluj D, Wiśniewska A, Szafrański KM, Cebula J, Gozdowski D, Podlaski S (2014) Assessment of the physiological responses to drought in different sugar beet genotypes in connection with their genetic distance. J Plant Physiol 171:1221-1230

Ciganda V, Gitelson A, Schepers J (2008) Vertical profile and temporal variation of chlorophyll in maize canopy: quantitative "crop vigor" indicator by means of reflectance-based techniques. Agron J 100:1409-1417

Cunha AR, Martins D (2009) Classificação climática para os municípios de Botucatu e São Manuel, SP. Irriga 14:1-11

Dias MC, Brüggemann W (2010) Limitations of photosynthesis in Phaseolus vulgaris under drought stress: gas exchange, chlorophyll fluorescence and calvin cycle enzymes. Photosynthetica 48:96-102

Dourado Neto D, Nielsen DR, Hopans JW, Parlange MB (1995) Programa SWRC, Version 3.0: soil-water retention curve (software). Piracicaba, Davis

Duque LO, Setter TL (2013) Cassava response to water deficit in deep pots: root and shoot growth, ABA, and carbohydrate reserves in stems, leaves and storage roots. Tropical Plant Biol 6:199-209

Egea G, Dodd IC, González-Real MM, Domingo R, Baille A (2011) Partial root-zone drying improves almond tree leaf-level water use efficiency and afternoon water status compared with regulated deficit irrigation. Funct Plant Biol 38:372-385

El-Sharkawy MA (1993) Drought-tolerant cassava for Africa, Asia, and Latin America. Bioscience 43:441-451

El-Sharkawy MA (2003) Cassava biology and physiology. Plant Mol Biol 53:621-641

El-Sharkawy MA (2004) Cassava biology and physiology. Plant Mol Biol 56:481-501

El-Sharkawy MA (2006) International research on cassava photosynthesis, productivity, eco-physiology, and responses to environmental stresses in the tropics. Photosynthetica 44:481-512

El-Sharkawy MA (2012) Stress-tolerant cassava: the role of integrative ecophysiology-breeding research in crop improvement. Open J Soil Sci 2:162-186

El-Sharkawy MA, Cock JH, Cadena G (1984) Stomatal characteristics among cassava cultivars and their relation to gas exchange. Exp Agric 20:67-76

Embrapa (2006) Centro Nacional de Pesquisa de Solos. Sistema brasileiro de classificação de solos. Embrapa SPI, Rio de Janeiro, p 306

Faria AP, Lemos-Filho JP, Modolo LV, França MGC (2013) Electrolyte leakage and chlorophyll $a$ fluorescence among castor bean cultivars under induced water deficit. Acta Physiol Plant 35:119-128

Ferreira DF (2008) SISVAR: a computer statistical analysis system. Ciênc Agrotec 35:1039-1042

Foyer CH, Noctor G (2000) Oxygen processing in photosynthesis: regulation and signaling. New Phytol 146:359-388

Guo XY, Zhang XS, Huang ZY (2010) Drought tolerance in three hybrid poplar clones submitted to different watering regimes. J Plant Ecol 3:79-87

Heaton JW, Marangoni AG (1996) Chlorophyll degradation in processed foods and senescent plant tissues. Trends Food Sci Technol $7: 8-15$

Inman-Bamber NG, Smith DM (2005) Water relations in sugarcane and response to water deficits. Field Crops Res 92:185-202

Kocheva KV, Landjeva SP, Georgiev GI (2014) Variation in ion leakage parameters of two wheat genotypes with different $R h t B 1$ alleles in response to drought. J Biosci 39:753-759

Krause GH, Weis E (1991) Chlorophyll fluorescence and photosynthesis: the basics. Annu Rev Plant Physiol 42:313-349

Ku Y, Au-Yeung W, Yung Y, Li M, Wen C, Liu X, Lam H (2013) Drought stress and tolerance in soybean. In: Board JE (ed) A comprehensive survey of international soybean research: genetics, physiology, agronomy and nitrogen relationships. InTech, New York, pp 209-237 
Lafuente MT, Belver A, Guye MG, Salveit ME (1991) Effect of the temperature conditioning on chilling injury of cucumber cotyledons. Plant Physiol 95:443-449

Lake JA, Quick WP, Beerling DJ, Woodward FI (2001) Signals from mature to new leaves. Nature 411:154-155

Lawlor DW, Tezara W (2009) Causes of decreased photosynthetic rate and metabolic capacity in water-deficient leaf cells: a critical evaluation of mechanisms and integration of processes. Ann Bot 103:561-579

Lebot V (2009) Tropical root and tuber crops: cassava, sweet Potato, yams and aroids. Cabi, Wallingford, pp 39-47

Levitt J (1980) Water, radiation, salt and other stresses. Academic, New York, p 622

Li Y, Li H, Li Y, Zhang S (2017) Improving water-use efficiency by decreasing stomatal conductance and transpiration rate to maintain higher ear photosynthetic rate in drought-resistant wheat. Crop J 5:231-239

Lin K, Chao P, Yang C, Cheng W, Lo H, Chang T (2006) The effects of flooding and drought stresses on the antioxidant constituents in sweet potato leaves. Bot Stud 47:417-426

Liu X, Huang B (2008) Photosynthetic acclimation to high temperatures associated with heat tolerance in creeping bentgrass. J Plant Physiol 165:1947-1953

Lorenzi JO, Monteiro DA, Miranda Filho HS, Raij BV (1997) Raízes e tubérculos. Boletim Técnico 100, Recomendações de adubação e calagem para o Estado de São Paulo. Instituto Agronômico de Campinas, Campinas, pp 54-57

Majumdar RK, Chakladar BP, Mukherjee SK (1972) Selection and classification of mango root stocks in the nursery stage. Acta Hortic 24:101-106

Manivannan P, Rabert GA, Rajasekar M, Somasundaram R (2014) Drought stress-induced modification on growth and pigments composition in different genotypes of Helianthus annuus L. Curr Bot 5:7-13

Marques TA, Silva WH (2008) Crescimento vegetativo e maturação em três cultivares de cana-de-açúcar. Rev Biol Ciênc Terra $8: 54-60$

Maxwell K, Johnson GN (2000) Chlorophyll fluorescence: a practical guide. J Exp Bot 51:659-668

Miri HR, Armin M (2013) The interaction effect of drought and exogenous application of glycine betaine on corn (Zea mays L.). Euro J Exp Bio 3:197-206

Motsa NM, Modi AT, Mabhaudhi T (2015) Sweet potato (Ipomoea batatas L.) as a drought tolerant and food security crop. S Afr J Sci 111:1-8

Obidiegwu JE, Bryan GJ, Jones HG, Prashar A (2015) Coping with drought: stress and adaptive responses in potato and perspectives for improvement. Front Plant Sci 6:1-23

Oliveira SL, Macedo MMC, Porto MCM (1982) Efeito do déficit de água na produção de raízes de mandioca, Brasília. Pesq Agropec Bras 17:121-124

Otsubo AA, Lorenzi JO (2004) Cultivo da mandioca na região CentroSul do Brasil. Embrapa, Cruz das Almas, Dourados, p 116

Pompelli MF, Barata-Luís R, Vitorino HV, Gonçalves ER, Rolim EV, Santos MG, Almeida-Cortez JS, Ferreira VM, Lemos EE, Endres L (2010) Photosynthesis, photoprotection and antioxidant activity of purging nut under drought deficit and recovery. Biomass Bioener 34:1207-1215

Porra RJ, Thompson WA, Kriedemann PE (1989) Determination of accurate extinction coefficients and simultaneous equations for assaying chlorophylls $a$ and $b$ extracted with four different solvents: verification of the concentration of chlorophyll standards by atomic absorption spectroscopy. Biochim Biophys Acta 975:384-394

Rascher U, Liebig M, Lüttge U (2000) Evaluation of instant lightresponses curves of chlorophyll parameters obtained with a portable chlorophyll fluorometer on site in the field. Plant Cell Environ 23:1397-1405

Rudack K, Seddig S, Sprenger H, Köhl K, Uptmoor R, Ordon F (2017) Drought stress-induced changes in starch yield and physiological traits in potato. J Agro Crop Sci 1-12

Santisopasri V, Kurotjanawong K, Chotineeranat S, Piyachomkwan K, Sriroth K, Oates CG (2001) Impact of water stress on yield and quality of cassava starch. Ind Crops Prod 13:115-129

Santos RF, Carlesso R (1998) Déficit hídrico e os processos morfológico e fisiológico das plantas. Rev Bras Eng Agríc Ambient 2:287-294

Santos CM, Silva MA, Lima GPP, Bortolheiro FPAP, Brunelli MC, Holanda LA, Oliver R (2015) Physiological changes associated with antioxidant enzymes in response to sugarcane tolerance to water deficit and rehydration. Sugar Tech 17:291-304

Shah AR, Khan TM, Sadaqat HA, Chatha AA (2011) Alterations in leaf pigments in cotton (Gossypium hirsutum) genotypes subjected to drought stress conditions. Int J Agric Biol 13:902-908

Silva EN, Ferreira-Siva SL, Fontenele AV, Ribeiro RV, Viégas RA, Silveira JAG (2010) Photosynthetic changes and protective mechanisms against oxidative damage subjected to isolated and combined drought and heat stresses in Jatropha curcas plants. J Plant Physiol 167:1157-1164

Silva MA, Jifon JL, Santos CM, Jadoski CJ, Silva JAG (2013) Photosynthetic capacity and water use efficiency in sugarcane genotypes subject to water deficit during early growth phase. Braz Arch Biol Technol 56:735-748

Smith M, Segeren A, Santos Pereira L, Perrier A, Allen R (1991) Report on the expert consultation on procedures for revision of FAO guidelines for prediction of crop water requirements. FAOLand and Water Development Division, pp 28-31

Streit NM, Canterle LP, Canto MW, Hecktheuer LHH (2005) The chlorophylls. Ciênc Rural 35:748-755

Sun Y, Yan F, Cui X, Liu F (2014) Plasticity in stomatal size and density of potato leaves under different irrigation and phosphorus regimes. J Plant Physiol 171:1248-1255

Tafur SM, El-Sharkawy MA, Cadavid LF (1997) Response of cassava (Manihot esculenta Crantz) to water stress and fertilization. Photosynthetica 34:233-239

Taiz L, Zeiger E (2013) Fisiologia vegetal. Porto Alegre, Artmed, p 918

Tripathy JN, Zhang J, Robin S, Nguyen TT, Nguyen HT (2000) QTLs for cell-membrane stability mapped in rice (Oryza sativa L.) under drought stress. Theor Appl Genet 100:1197-1202

Turyagyenda LF, Kizito EB, Ferguson M, Baguma Y, Agaba M, Harvey JJW, Osiru DSO (2013) Physiological and molecular characterization of drought responses and identification of candidate tolerance genes in cassava. AoB Plants 5:1-17

Ulemale CS, Mate SN, Deshmukh DV (2013) Physiological indices for drought tolerance in chickpea (Cicer arietinum L.). World J Agric Sci 9:123-131

Usman M, Raheem Z, Ahsan T, Iqbal A, Sarfaraz ZN, Haq Z (2013) Morphological, physiological and biochemical attributes as indicators for drought tolerance in rice (Oryza sativa L.). Eur J Biol Sci 5:23-28

Van Genutchen MTH (1980) A closed-from equation for predicting the hydraulic conductivity of insatured. Soil Sci Soc Am J 41:892-898

Wedeking R, Mahlein A, Steiner U, Oerke E, Goldbach HE, Wimmer MA (2017) Osmotic adjustment of young sugar beets (Beta vulgaris) under progressive drought stress and subsequent rewatering assessed by metabolite analysis and infrared thermography. Funct Plant Biol 44:119-133

Wellburn AR (1994) The spectral determination of chlorophylls $a$ and $b$, as well as total carotenoids, using various solvents with spectrophotometers of different resolution. J Plant Physiol 144:307-313 
Yan F, Sun Y, Song F, Liu F (2012) Differential responses of stomatal morphology to partial root-zone drying and deficit irrigation in potato leaves under varied nitrogen rates. Sci Hortic 145:76-83

Yooyongwech S, Samphumphung T, Tisaram R, Theerawitaya C, ChaUm S (2017) Physiological, morphological changes and storage root yield of sweetpotato [Ipomoea batatas (L.) Lam.] under peginduced water stress. Not Bot Horti Agrobo 45:164-171

Zaefyzadeh M, Quliyev RA, Babayeva SM, Abbasov MA (2009) The effect of the interaction between genotypes and drought stress on the superoxide dismutase and chlorophyll content in durum wheat landraces. Turk J Biol 33:1-7
Zhang YP, Wang ZM, Wu YC, Zhang X (2006) Stomatal characteristics of different green organs in wheat under different irrigation regimes. Acta Agron Sin 32:70-75

Zhao L, Liu F, Xu W, Di C, Zhou S, Xue Y, Yu J, Su Z (2009) Increased expression of OsSPX1 enhances cold/subfreezing tolerance in tobacco and Arabidopsis thaliana. Plant Biotechnol J 7:550-561

Zhao W, Sun Y, Kjelgren R, Liu X (2015) Response of stomatal density and bound gas exchange in leaves of maize to soil water deficit. Acta Physiol Plant 37:1704-1712 